\title{
$\beta$-Endorphin and met-enkephalin in plasma of cattle during pregnancy, parturition and the neonatal period
}

\author{
J. E. Aurich, I. Dobrinski, H.-O. Hoppen* and E. Grunert \\ Klinik für Geburtshilfe und Gynäkologie des Rindes und * Abt. für Endokrinologie, \\ Tierärztliche Hochschule, Hannover, FRG
}

\begin{abstract}
Summary. Plasma concentrations of $\beta$-endorphin and met-enkephalin were measured, with appropriate radioimmunoassays, in cows during gestation and at parturition and in newborn calves. During pregnancy $\beta$-endorphin immunoreactivity (IR) concentration increased, but values during the last month of gestation were not different from those at parturition. Highest met-enkephalin IR levels were obtained in cows during calving. A term Caesarean section caused an increase in plasma $\beta$-endorphin and metenkephalin IR concentrations, but no such increase occurred in cases of a preterm Caesarean section. In calves $\beta$-endorphin IR values were lower before umbilical cord rupture than immediately after birth. Values decreased continuously thereafter. This was also the case for met-enkephalin IR concentrations in calves born at term. In preterm calves met-enkephalin IR values were low immediately after delivery and increased during the first hour of life. A significant correlation existed between the degree of acidosis and plasma levels of both opioid peptides in the calves. We conclude that a direct stimulation of peripheral $\beta$-endorphin release by the pain or stress associated with calving does not seem to exist in cattle, whereas met-enkephalin seems to be more directly related to parturition. In calves the change to the extrauterine environment causes an immediate, increased release of both opioids.
\end{abstract}

Keywords: $\beta$-endorphin; met-enkephalin; cattle; parturition; neonate

\section{Introduction}

Opioid peptides have been implicated in the modulation of pain and stress. Parturition and delivery are particularly stressful situations for the mother as well as for the neonate. During labour, opioid peptides in the central nervous system lead to an increase in the pain threshold (Wardlaw \& Frantz, 1983; Baron \& Gintzler, 1987). In addition to this enhanced CNS opioid activity, several investigators have reported elevated $\beta$-endorphin concentrations in peripheral plasma of women during parturition (Goland et al., 1981; Steinbrook et al., 1982; Hoffman et al., 1984). Also in newborn human babies and lambs, high plasma $\beta$-endorphin concentrations have been found, especially in conjunction with fetal distress (Wardlaw et al., 1979; Ruth et al., 1986; Skillman \& Clark, 1987). Although the role of peripheral $\beta$-endorphin has not yet been clarified, participation in the stress response has been postulated. Little is known about plasma enkephalin concentrations in the mother, fetus and neonate around parturition. Despite the facts that enkephalins are released with catecholamines from the adrenal gland in haemorrhagic shock (Watson et al., 1988), and that plasma catecholamines are known to be significantly elevated in newborns (Irestedt et al., 1982), plasma enkephalin levels in neonates have not yet been reported. We have investigated plasma $\beta$-endorphin and met-enkephalin immunoreactivity in cows submitted to different obstetrical procedures and their newborn calves as well as in pregnant cows. If peripheral opioid peptides are 
released in response to the stress of labour and delivery, low plasma concentrations should be expected in all animals except cows actually in labour and newborn calves.

\section{Materials and Methods}

Animals and procedures. In 51 cows and their calves blood samples were taken during parturition and immediately post partum and post natum as well as 1,12 and $48 \mathrm{~h}$ thereafter. Of the cows, 33 were primiparous and 18 multiparous, 31 neonates were male and 20 female calves. Cows and newborn calves were assigned to 4 different groups. In Group 1 , the cows $(N=13)$ delivered spontaneously at term with no obstetrical assistance. In Group $2(\mathrm{~N}=12)$, delivery was at term but was accompanied by dystocia and forced extraction. In Group $3(N=14)$ term delivery was accompanied by dystocia and Caesarean section. In Group $4(\mathrm{~N}=12)$, Caesarean section was performed before term. The cows of Group 4 were slaughtered the day after surgery.

Samples were also taken from cows in the $3 \mathrm{rd}(\mathrm{N}=4), 6$ th $(\mathrm{N}=6)$ and 9 th $(\mathrm{N}=7)$ month of gestation, bringing the total number of cows sampled to 68: 64 cows were of the German Black Pied breed and the remaining cows were German Simmental $(N=2)$, Charolais $(N=1)$ and German Red Pied $(N=1)$ cattle. Of the calves, 46 were of the same breed as their dams and 5 neonates were crossbreds of German Black Pied cows and beef bulls. Animals of Groups 1, 2 and 3 were patients admitted to the Clinic for Bovine Obstetrics and Gynaecology because of dystocia or for surveillance of parturition. The cows of Group 4 were research animals. Cows with twins, a dead fetus, diseases and complications except dystocia or with induced parturition were excluded. Caesarean sections were performed under local anaesthesia with the cow standing or in sternal recumbency; no sedative or general analgesic was administered. Isoxsupprine lactate (Uterusrelaxans: WDT, Hannover, FRG) was given to relax the uterus.

Cows were housed in tie stalls with straw bedding and fed concentrate and hay; calves were kept in individual stalls on straw and fed colostrum.

Blood $(10 \mathrm{ml})$ was collected into frozen polypropylene tubes containing $25 \mathrm{mg}$ EDTA and $5000 \mathrm{I} . \mathrm{U}$. aprotinin (Trasylol: Bayer, Leverkusen, FRG), kept on ice, centrifuged at $4^{\circ} \mathrm{C}$ immediately and stored at $-20^{\circ} \mathrm{C}$. Blood was taken from the jugular or the subcutaneous abdominal vein. In all cases of Caesarean section additional samples were taken from an intact umbilical artery and vein before rupture of the umbilical cord. In cows plasma progesterone concentration was determined in addition to $\beta$-endorphin and met-enkephalin values. For calves venous blood was taken at the time of sampling for blood gas analysis on an autoanalyzer (ABL 3, Radiometer, Copenhagen, Denmark).

Peptides and reagents. Peptides were obtained from the following sources: human ACTH from the National Institute of Diabetes and Digestive and Kidney Diseases (NIDDK), Baltimore, MD, USA; human $\beta$-lipotropin from the National Institute of Arthritis, Metabolism and Digestive Diseases (NIAMDD), Torrance, CA, USA; human and camel $\beta$-endorphin from Bissendorf Biochemicals, Hannover, FRG; met-enkephalin, leu-enkephalin, dynorphin 1-8 and 1-13 from Sigma Chemie, Deisenhofen, FRG. Methanol and acetonitrile of chromatography grade were used and all other reagents were analytical grade.

Peptide extraction. Before extraction samples were centrifuged to remove fibrin. Peptides were extracted from plasma with Sep-Pak C-18-cartridges (Waters Chromatographie, Eschborn, FRG) at $4^{\circ} \mathrm{C}$. All extractions were performed in duplicate. The cartridges were activated with $5 \mathrm{ml}$ methanol and double-distilled water. For $\beta$-endorphin extraction, $0.5-3 \mathrm{ml}$ plasma were slowly passed through the cartridge, then the cartridge was washed with $5 \mathrm{ml} 4 \%$ acetic acid $(\mathrm{v} / \mathrm{v})$ and double-distilled water and $\beta$-endorphin was eluted with $2 \mathrm{ml} 1 \%$ trifluoroacetic acid in $80 \%$ methanol $(\mathrm{v} / \mathrm{v})$. For met-enkephalin extraction the method described by Clement-Jones et al. (1980) was used with slight modifications. Plasma was acidified with glycine-- $\mathrm{HCl}$ buffer $(0.2 \mathrm{M}$-glycine in $1 \mathrm{M}-\mathrm{HCl}, 150 \mu \mathrm{l} / \mathrm{ml}$ plasma). After application of $0.5-3 \mathrm{ml}$ plasma the cartridges were washed with $0.8 \mathrm{ml}$ of a solution of $0.15 \mathrm{M}-\mathrm{NaCl}$ containing $1 \%$ formic acid $(\mathrm{v} / \mathrm{v}), 1.5 \% 1 \mathrm{M}-\mathrm{HCl}(\mathrm{v} / \mathrm{v})$ and $3 \mathrm{mM}-\mathrm{glycine}$ and with $0.8 \mathrm{ml} 1 \%$ formic acid $(\mathrm{v} / \mathrm{v})$.

Met-enkephalin was eluted with $1.6 \mathrm{ml} 1 \%$ formic acid in $80 \%$ methanol (v/v). $\beta$-Endorphin and met-enkephalin extracts were evaporated to dryness in a vacuum centrifuge (Hetovac VR 1, Nunc, Wiesbaden, FRG) and stored at $-20^{\circ} \mathrm{C}$ until resuspension in RIA buffer $(600 \mu \mathrm{l})$ and transfer into RIA $(400 \mu \mathrm{l})$.

HPLC. After extraction selected samples were subjected to reverse-phase HPLC on a C-18 column (Bischoff, Leonberg, FRG) using an LKB 2150 pump and 2151 controller (Pharmacia LKB, Freiburg, FRG). The column was eluted with a linear gradient of 0 to $70 \%$ solvent B over $55 \mathrm{~min}$ at a flow of $0.6 \mathrm{ml} / \mathrm{min}$. Solvent A was $0.1 \%$ trifluoroacetic acid in $20 \%$ acetonitrile $(\mathrm{v} / \mathrm{v})$ and solvent $\mathrm{B}$ was $70 \%$ acetonitrile. The $0.6-\mathrm{ml}$ fractions were collected, dried down in a vacuum centrifuge and stored at $-20^{\circ} \mathrm{C}$ until radioimmunoassay.

Radioimmunoassay. All RIAs were performed in polypropylene tubes on ice. $\beta$-Endorphin was measured using camel $\beta$-endorphin standard and an ovine antiserum raised against camel (=bovine) $\beta$-endorphin bound to pig thyroglobulin (Ebling \& Lincoln, 1987). On a molar basis the antiserum cross-reacted $100 \%$ with human $\beta$-lipotropin, $70 \%$ with human $\beta$-endorphin and $<0.01 \%$ with leu-enkephalin, met-enkephalin, dynorphin 1-8, dynorphin 1-13 and human ACTH. The antiserum was used at a dilution of $1: 25000$ in $0.01 \mathrm{M}-\mathrm{PBS}(\mathrm{pH} 7.4)$ with $0.05 \mathrm{M}-\mathrm{EDTA}, 0.1 \%$ gelatine $(\mathrm{w} / \mathrm{v})$ and $0.25 \%$ normal sheep serum $(\mathrm{v} / \mathrm{v})$. Standards $(50 \mu \mathrm{l})$ or resuspended sample extracts $(400 \mu \mathrm{l})$ were incubated with $100 \mu \mathrm{l}$ antiserum in a total volume of $700 \mu 10.01 \mathrm{M}-\mathrm{PBS}(\mathrm{pH} 7.4)$ containing $0.1 \%$ gelatine $(\mathrm{w} / \mathrm{v})$ and 
$0.1 \%$ bovine serum albumin $\left(\mathrm{w} / \mathrm{v} ; \beta\right.$-E buffer) for $24 \mathrm{~h}$ at $4^{\circ} \mathrm{C}$. For determination of non-specific binding normal sheep serum at a dilution of 1:400 was used instead of antiserum. ${ }^{125} \mathrm{I}$-labelled $\beta$-endorphin (human; Amersham Buchler, Braunschweig, FRG) was used as tracer at a dilution of 20000 c.p.m. $/ 100 \mu \mathrm{l}$ in $\beta$-E buffer containing $0.1 \%$ Triton $\mathrm{X}-100(\mathrm{v} / \mathrm{v})$. After addition of the tracer incubation was continued for another $24 \mathrm{~h}$ at $4^{\circ} \mathrm{C}$. Bound and free ligands were separated by Dextran-coated charcoal $(500 \mu \mathrm{l}$ of a $12 \mathrm{mg} / \mathrm{ml}$ suspension per tube, incubation for $10 \mathrm{~min}$ at $4^{\circ} \mathrm{C}$ ). Bound ${ }^{125} \mathrm{I}$-labelled $\beta$-endorphin in the supernatant was measured in a gamma-counter (Multigamma 1261, Pharmacia LKB, Freiburg, FRG). The minimal detectable concentration of this assay was $19 \mathrm{pg}, 50 \%$ displacement of the tracer occurred at $170 \mathrm{pg}$, non-specific binding was $4 \%$. Intra- and interassay variation were, respectively, $5.9 \%$ and $9.2 \%$ for RIA and $9.6 \%$ and $11.9 \%$ for extraction and RIA.

Met-enkephalin was measured with an antiserum raised in rabbits (Amersham Buchler, Braunschweig, FRG). The antiserum cross-reacted $8 \%$ with leu-enkephalin and $<0.01 \%$ with human and camel $\beta$-endorphin, human $\beta$ lipotropin, dynorphin 1-8, dynorphin 1-13 and human ACTH. The antiserum was diluted to a final concentration of 1:60000 in $0.05 \mathrm{M}-\mathrm{NaH}_{2} \mathrm{PO}_{4}$ (pH 7.4) containing 0.01 M-EDTA and $0.2 \%$ gelatine (w/v; ME buffer). ${ }^{125} \mathrm{I}$-labelled met-enkephalin (Amersham Buchler, Braunschweig, FRG) was used as tracer at a dilution of 10000 c.p.m./100 $\mu$ in ME buffer. After addition of antiserum or normal rabbit serum $(100 \mu \mathrm{l})$ at a dilution of 1:60 000 in $\mathrm{ME}$ buffer for nonspecific binding and tracer $(100 \mu l)$ met-enkephalin standards $(50 \mu l)$ or sample extracts $(400 \mu l)$ were incubated in a total volume of $800 \mu \mathrm{l} \mathrm{ME}$ buffer for $24 \mathrm{~h}$ at $4^{\circ} \mathrm{C}$. Bound and free ligands were separated as described for $\beta$-endorphin. The minimal detectable concentration of the met-enkephalin assay was $3.5 \mathrm{pg}, 50 \%$ displacement of the tracer occurred at $30 \mathrm{pg}$, non-specific binding was $5 \%$. The intra- and interassay variations were, respectively, $7 \cdot 4 \%$ and $16.0 \%$ for the RIA and $13.7 \%$ and $18.9 \%$ for extraction and RIA.

Progesterone was determined by RIA after extraction with ether as described by Hoffmann et al. (1973).

Statistical analysis. Analysis of variance for repeated measures and additional one-way analysis of variance with subsequent Tukey's test for comparison between groups were performed. Jugular vein and umbilical samples in calves were compared by paired samples $t$ tests. All values given are means \pm standard error of mean (s.e.m.). The sensitivity limit of the radioimmunoassays was defined as three standard deviations from zero binding.

\section{Results}

\section{Extraction}

The extraction recovery of $\beta$-endorphin and met-enkephalin standards added to plasma was $86 \%$ and $89 \%$, respectively. Increasing amounts of plasma $(0 \cdot 5-3 \mathrm{ml})$ displaced tracer bound to the antibody in both RIAs in a manner parallel to the standard curves.

\section{HPLC}

In the HPLC, $\beta$-endorphin immunoreactivity (IR) eluted in one peak in the same position as camel $\beta$-endorphin standard. However, a clear separation of $\beta$-endorphin and $\beta$-lipotropin could not be accomplished with our chromatography system. Met-enkephalin IR eluted in two peaks, one in the same position as met-enkephalin standard; the other was smaller and less distinct and did not correspond with any other peptide tested.

\section{Plasma progesterone}

Plasma progesterone concentrations were $17.7 \pm 3.6,7.9 \pm 0.8$ and $5.5 \pm 1.4 \mathrm{ng} / \mathrm{ml}$ for animals in the $3 \mathrm{rd}$, 6th and 9 th month of gestation, respectively. Cows in which a preterm Caesarean section was performed (Group 4) had a mean progesterone value of $8.3 \pm 0.9 \mathrm{ng} / \mathrm{ml}$. In the other cows with term parturition (Groups 1,2,3) mean values of $0.8 \pm 0 \cdot 1,1.3 \pm 0.3$ and $1 \cdot 2 \pm 0 \cdot 2 \mathrm{ng} / \mathrm{ml}$ were measured.

\section{Plasma $\beta$-endorphin and met-enkephalin}

$\beta$-Endorphin and met-enkephalin IR concentrations in pregnant cows and animals with term vaginal delivery (Groups 1 and 2 ) are shown in Table 1 . Highest $\beta$-endorphin IR values were reached in the last month of gestation before pre-partum luteolysis. In contrast, met-enkephalin concentrations during parturition were higher than during any other stage of gestation. 
$\beta$-Endorphin and met-enkephalin IR concentrations during the period at parturition in cows and calves are shown in Tables 2 and 3 . In cows with vaginal delivery and in all calves $\beta$-endorphin IR concentrations decreased continuously during the first 2 days post partum. In cows with a Caesarean section performed, highest $\beta$-endorphin IR concentrations were measured during surgery. For $\beta$-endorphin, analysis of variance for repeated measures revealed significant differences between different sampling times for cows and calves $(P<0.05)$, but significant interactions between groups and times could only be shown in cows $(P<0.05)$. Calves delivered by preterm Caesarean section (Group 4) showed significantly higher $\beta$-endorphin IR levels at $1 \mathrm{~h}$ after birth than did calves born spontaneously (Group 1).

Table 1. Concentrations of immunoreactive $\beta$-endorphin and met-enkephalin in plasma of pregnant and calving cows (vaginal delivery)

\begin{tabular}{lccc}
\hline Group & $\begin{array}{c}\text { No. of } \\
\text { cows }\end{array}$ & $\begin{array}{c}\beta \text {-Endorphin } \\
(\mathrm{pg} / \mathrm{ml})\end{array}$ & $\begin{array}{c}\text { Met-enkephalin } \\
(\mathrm{pg} / \mathrm{ml})\end{array}$ \\
\hline 3rd month & 4 & $30 \cdot 1 \pm 1 \cdot 6^{\mathrm{a}}$ & $5 \cdot 5 \pm 1 \cdot 0^{\mathrm{a}}$ \\
6th month & 6 & $50 \cdot 1 \pm 10 \cdot 2^{\mathrm{a}, \mathrm{b}}$ & $5 \cdot 0 \pm 1 \cdot 2^{\mathrm{a}}$ \\
9th month & 7 & $104 \cdot 3 \pm 23 \cdot 8^{\mathrm{b}}$ & $16 \cdot 4 \pm 2 \cdot 7^{\mathrm{a}, \mathrm{b}}$ \\
$\begin{array}{l}\text { Vaginal } \\
\text { delivery* }\end{array}$ & 25 & $90 \cdot 5 \pm 8 \cdot 0^{\mathrm{a}, \mathrm{b}}$ & $34 \cdot 3 \pm 4 \cdot 5^{\mathrm{b}}$ \\
\hline
\end{tabular}

*Animals of Groups 1 and 2.

Values are mean \pm s.e.m.

Values in the same column with different letters are significantly different, $P<0.05$.

Table 2. Concentrations of IR $\beta$-endorphin ( $\mathrm{pg} / \mathrm{ml})$ in plasma of cows and calves in Groups $1-4^{*}$

\begin{tabular}{|c|c|c|c|c|c|c|c|c|c|}
\hline \multirow[b]{2}{*}{ Group } & \multirow{2}{*}{$\begin{array}{l}\text { No. of } \\
\text { cows and } \\
\text { calves }\end{array}$} & \multicolumn{4}{|c|}{ Cows post partum } & \multicolumn{4}{|c|}{ Calves after birth } \\
\hline & & Oh & $1 \mathrm{~h}$ & $12 \mathrm{~h}$ & $48 \mathrm{~h}$ & $0 \mathrm{~h}$ & $1 \mathrm{~h}$ & $12 \mathrm{~h}$ & $48 \mathrm{~h}$ \\
\hline 1 & 13 & $\begin{array}{r}73 \cdot 0^{\mathrm{a}} \\
\pm 11 \cdot 1\end{array}$ & $\begin{array}{l}74 \cdot 7^{a} \\
\pm 12 \cdot 0\end{array}$ & $\begin{array}{l}47.7^{\mathrm{a}} \\
\pm 5.4\end{array}$ & $\begin{array}{l}48 \cdot 6^{a} \\
\pm 4 \cdot 1\end{array}$ & $\begin{array}{l}471 \cdot 8^{a} \\
\pm 54.4\end{array}$ & $\begin{array}{l}206 \cdot 3^{\mathrm{a}} \\
\pm 25 \cdot 4\end{array}$ & $\begin{array}{l}252 \cdot 5^{a} \\
\pm 50 \cdot 3\end{array}$ & $\begin{array}{l}234 \cdot 7^{a} \\
\pm 37 \cdot 2\end{array}$ \\
\hline 2 & 12 & $\begin{array}{l}109 \cdot 4^{a} \\
\pm 9.0\end{array}$ & $\begin{array}{l}89 \cdot 2^{a, b} \\
\pm 15 \cdot 6\end{array}$ & $\begin{array}{l}74 \cdot 8^{a, b} \\
\pm 10 \cdot 3\end{array}$ & $\begin{array}{l}55 \cdot 4^{a} \\
\pm 3.9\end{array}$ & $\begin{array}{l}544 \cdot 1^{a} \\
\pm 40 \cdot 7\end{array}$ & $\begin{array}{c}238.9^{\mathrm{a}, \mathrm{b}} \\
\pm 23.6\end{array}$ & $\begin{array}{l}244 \cdot 3^{a} \\
\pm 29 \cdot 4\end{array}$ & $\begin{array}{l}216.8^{a} \\
\pm 66.1\end{array}$ \\
\hline 3 & 14 & $\begin{array}{r}95 \cdot 2^{\mathrm{a}} \\
\pm 16.8\end{array}$ & $\begin{array}{c}162.9^{b} \\
\pm 30 \cdot 1\end{array}$ & $\begin{array}{l}74 \cdot 1^{a, b} \\
\pm 12 \cdot 2\end{array}$ & $\begin{array}{l}74.9^{\mathrm{a}} \\
\pm 15.6\end{array}$ & $\begin{array}{l}506 \cdot 2^{\mathrm{a}} \\
\pm 56 \cdot 1\end{array}$ & $\begin{array}{c}260 \cdot 6^{a \cdot b} \\
\pm 39 \cdot 0\end{array}$ & $\begin{array}{l}197 \cdot 8^{a} \\
\pm 24 \cdot 5\end{array}$ & $\begin{array}{l}192.8^{\mathrm{a}} \\
\pm 27.8\end{array}$ \\
\hline 4 & 12 & $\begin{array}{r}101 \cdot 0^{2} \\
\pm \quad 9.2\end{array}$ & $\begin{array}{c}122 \cdot 3^{\mathrm{a}, \mathrm{b}} \\
\pm 21 \cdot 6\end{array}$ & $\begin{array}{l}95 \cdot 8^{b} \\
\pm 18 \cdot 1\end{array}$ & - & $\begin{array}{l}543 \cdot 5^{\mathrm{a}} \\
\pm 54 \cdot 7\end{array}$ & $\begin{array}{c}344 \cdot 8^{\mathrm{b}} \\
\pm 33 \cdot 1\end{array}$ & $\begin{array}{l}279 \cdot 1^{a} \\
\pm 31 \cdot 7\end{array}$ & $\begin{array}{l}269 \cdot 2^{a} \\
\pm 40 \cdot 4\end{array}$ \\
\hline
\end{tabular}

*Group 1: spontaneous term delivery; Group 2: term delivery, dystocia, forced extraction; Group 3: term delivery, dystocia, Caesarean section; Group 4: pre-term Caesarean section.

Values are mean \pm s.e.m.

Values in the same column with different letters are significantly different, $P<0.05$ (one-way analysis of variance).

For analysis of variance for repeated measures: (1) differences between groups, cows: $P=0.05$; calves: $P>0.05 ;$; 2 ) differences between times, cows: $P<0.05$; calves: $P<0.05$; (3) interactions of groups $\times$ times, cows: $P<0.05$; calves: $P>0.05$.

In all cows with vaginal delivery (Groups 1 and 2) and in calves born at term (Groups 1-3) IR met-enkephalin concentrations decreased continuously during the first 2 days after parturition. In cows with term Caesarean section as well as in premature calves, highest values were measured $1 \mathrm{~h}$ after delivery; no changes could be detected in cows with preterm Caesarean section. For met- 
Table 3. Concentrations of IR met-enkephalin $(\mathrm{pg} / \mathrm{ml})$ in plasma of cows and calves in Groups $1-4^{*}$

\begin{tabular}{|c|c|c|c|c|c|c|c|c|c|}
\hline \multirow[b]{2}{*}{ Group } & \multirow{2}{*}{$\begin{array}{l}\text { No. of } \\
\text { cows and } \\
\text { calves }\end{array}$} & \multicolumn{4}{|c|}{ Cows post partum } & \multicolumn{4}{|c|}{ Calves after birth } \\
\hline & & $0 \mathrm{~h}$ & $1 \mathrm{~h}$ & $12 \mathrm{~h}$ & $48 \mathrm{~h}$ & $0 \mathrm{~h}$ & $1 \mathrm{~h}$ & $12 \mathrm{~h}$ & $48 \mathrm{~h}$ \\
\hline 1 & 13 & $\begin{array}{l}34 \cdot 0^{\mathrm{a}} \\
\pm 7 \cdot 1\end{array}$ & $\begin{array}{r}23 \cdot 8^{a} \\
\pm 5 \cdot 3\end{array}$ & $\begin{array}{l}14 \cdot 5^{\mathrm{a}} \\
\pm \quad 3.5\end{array}$ & $\begin{array}{l}17.9^{\mathrm{a}} \\
\pm 6.9\end{array}$ & $\begin{array}{c}50.5^{\mathrm{a}} \\
\pm 15.8\end{array}$ & $\begin{array}{l}31 \cdot 5^{a} \\
\pm 56\end{array}$ & $\begin{array}{r}23 \cdot 7^{a} \\
\pm 4 \cdot 2\end{array}$ & $\begin{array}{l}10 \cdot 2^{\mathrm{a}} \\
\pm 2 \cdot 0\end{array}$ \\
\hline 2 & 12 & $\begin{array}{l}34.7^{\mathrm{a}} \\
\pm \quad 5.8\end{array}$ & $\begin{array}{l}22 \cdot 1^{a} \\
\pm 3 \cdot 3\end{array}$ & $\begin{array}{l}13 \cdot 3^{\mathrm{a}} \\
\pm \quad 2 \cdot 3\end{array}$ & $\begin{array}{l}11.9^{\mathrm{a}} \\
\pm 2.2\end{array}$ & $\begin{array}{c}90 \cdot 5^{\mathrm{a}} \\
\pm 24 \cdot 5\end{array}$ & $\begin{array}{l}60 \cdot 7^{\mathrm{a}} \\
\pm 19 \cdot 2\end{array}$ & $\begin{array}{l}21 \cdot 7^{\mathrm{a}} \\
\pm 4 \cdot 2\end{array}$ & $\begin{array}{l}12 \cdot 7^{\mathrm{a}} \\
\pm 2 \cdot 3\end{array}$ \\
\hline 3 & 14 & $\begin{array}{l}21 \cdot 3^{\mathrm{a}} \\
\pm 2 \cdot 6\end{array}$ & $\begin{array}{l}31 \cdot 5^{\mathrm{a}} \\
\pm 3 \cdot 8\end{array}$ & $\begin{array}{l}23 \cdot 5^{\mathrm{a}} \\
\pm 10 \cdot 6\end{array}$ & $\begin{array}{l}12.6^{3} \\
\pm 2.5\end{array}$ & $\begin{array}{l}81.9^{\mathrm{a}} \\
\pm 18.9\end{array}$ & $\begin{array}{l}44.0^{\mathrm{a}} \\
\pm 7.5\end{array}$ & $\begin{array}{l}21 \cdot 2^{2} \\
\pm 2 \cdot 6\end{array}$ & $\begin{array}{l}12 \cdot 3^{\mathrm{a}} \\
\pm 2 \cdot 3\end{array}$ \\
\hline 4 & 12 & $\begin{array}{l}21 \cdot 5^{\mathrm{a}} \\
\pm 2.4\end{array}$ & $\begin{array}{l}18 \cdot 0^{\mathrm{a}} \\
\pm 2 \cdot 0\end{array}$ & $\begin{array}{l}21.0^{\mathrm{a}} \\
\pm \quad 2.4\end{array}$ & - & $\begin{array}{l}24 \cdot 4^{\mathrm{a}} \\
\pm \quad 3 \cdot 3\end{array}$ & $\begin{array}{l}39.0^{\mathrm{a}} \\
\pm 4.5\end{array}$ & $\begin{array}{r}22.4^{a} \\
\pm 2.8\end{array}$ & $\begin{array}{r}17 \cdot 6^{\mathrm{a}} \\
\pm 3 \cdot 1\end{array}$ \\
\hline
\end{tabular}

*Group 1: spontaneous term delivery; Group 2: term delivery, dystocia, forced extraction; Group 3: term delivery, dystocia, Caesarean section; Group 4: pre-term Caesarean section.

Values are mean \pm s.e.m.

Values in the same column with different letters are significantly different, $P<0.05$ (one-way analysis of variance).

For analysis of variance for repeated measures: (1) differences between groups, cows: $P>0.05$; calves: $P>0.05 ;(2)$ differences between times, cows: $P<0.05$; calves: $P<0.05$; (3) interactions of groups $\times$ times, cows: $P<0.05$; calves: $P<0.05$.

enkephalin significant differences between groups could not be detected in cows or calves. Differences for times and interactions between groups and times were significant for cows as well as for calves $(P<0.05)$.

As shown in Tables 4 and $5, \beta$-endorphin concentrations in term and preterm calves and met-enkephalin values in preterm calves were significantly lower in both umbilical vessels than in the jugular vein immediately after (i.e. $1 \mathrm{~min}$ ) birth. In preterm calves only the difference between umbilical and jugular vein met-enkephalin IR levels was significant $(P<0 \cdot 05)$. No significant differences existed for $\beta$-endorphin IR values in term and preterm calves or between umbilical artery and vein. However, met-enkephalin IR concentrations in both umbilical vessels were significantly lower when delivery was before term than in calves delivered at term by Caesarean section $(P<0.05)$. No effect of sex of calf or parity of the cow on plasma opioids could be detected.

Table 4. Concentrations ( $\mathrm{pg} / \mathrm{ml})$ of IR $\beta$-endorphin in the umbilical artery and vein before rupture of the umbilical cord and in the jugular vein immediately after delivery in calves delivered by term (Group 3) and preterm (Group 4) Caesarean section

\begin{tabular}{ccccc}
\hline Group & $\begin{array}{c}\text { No. of } \\
\text { animals }\end{array}$ & $\begin{array}{c}\text { Umbilical } \\
\text { artery }\end{array}$ & $\begin{array}{c}\text { Umbilical } \\
\text { vein }\end{array}$ & $\begin{array}{c}\text { Jugular } \\
\text { vein }\end{array}$ \\
\hline 3 & 14 & $428 \cdot 6 \pm 53 \cdot 0^{\mathrm{a} \cdot \mathrm{A}}$ & $419 \cdot 1 \pm 52 \cdot 3^{\mathrm{a} \cdot \mathrm{A}}$ & $506 \cdot 2 \pm 56 \cdot 1^{\mathrm{a}, \mathrm{B}}$ \\
4 & 12 & $371 \cdot 8 \pm 47 \cdot 0^{\mathrm{a} \cdot \mathrm{A}}$ & $342 \cdot 6 \pm 33 \cdot 4^{\mathrm{a} \cdot \mathrm{A}}$ & $543 \cdot 5 \pm 54 \cdot 7^{\mathrm{a}, \mathrm{B}}$ \\
\hline
\end{tabular}

${ }^{a}$ Values with the same index in the same column are not significantly different $(P>0.05)$.

${ }^{\mathrm{A}, \mathrm{B}}$ Values with a different index in the same line are significantly different $(P<0.05)$.

Values are mean \pm s.e.m.

\section{Correlation between plasma opioids and acidosis in calves}

A significant negative correlation $(P<0.001)$ was noted between met-enkephalin IR and the venous $\mathrm{pH}(r=-0.755)$ and base excess $(r=-0.790)$ in newborn calves immediately 
Table 5. Concentrations $(\mathrm{pg} / \mathrm{ml})$ of IR met-enkephalin in the umbilical artery and vein before rupture of the umbilical cord and in the jugular vein immediately after delivery in calves delivered by term

(Group 3) and pre-term (Group 4) Caesarean section

\begin{tabular}{ccccc}
\hline Group & $\begin{array}{c}\text { No. of } \\
\text { animals }\end{array}$ & $\begin{array}{c}\text { Umbilical } \\
\text { artery }\end{array}$ & $\begin{array}{c}\text { Umbilical } \\
\text { vein }\end{array}$ & $\begin{array}{c}\text { Jugular } \\
\text { vein }\end{array}$ \\
\hline 3 & 14 & $48 \cdot 6 \pm 11 \cdot 2^{\mathrm{a}, \mathrm{A}}$ & $43 \cdot 2 \pm 9 \cdot 4^{\mathrm{a}, \mathrm{A}}$ & $81 \cdot 9 \pm 18 \cdot 9^{\mathrm{a}, \mathrm{B}}$ \\
4 & 12 & $19 \cdot 3 \pm 5 \cdot 3^{\mathrm{b}, \mathrm{A}, \mathrm{B}}$ & $13 \cdot 4 \pm 2 \cdot 3^{\mathrm{b}, \mathrm{B}}$ & $24 \cdot 4 \pm 3 \cdot 3^{\mathrm{a}, \mathrm{A}}$ \\
\hline
\end{tabular}

a.b Values with the same index in the same column are not significantly different $(P>0.05)$.

${ }^{A}, \mathbf{B}$ Values with a different index in the same line are significantly different $(P<0.05)$.

Values are mean \pm s.e.m.

after delivery. A significant correlation $(P<0.05)$ existed also between $\beta$-endorphin and $\mathrm{pH}$ $(r=-0 \cdot 286)$, but no significant correlation could be found between $\beta$-endorphin IR and base excess values.

\section{Discussion}

In the present study we measured plasma concentrations of two endogenous opioids in cattle during pregnancy, parturition, early puerperium and in the neonatal period. $\beta$-Endorphin and $\beta$-lipotropin were not separated by our HPLC procedure. Met-enkephalin IR was eluted in two positions, one identical to met-enkephalin standard, the second not corresponding to any other peptide tested. This second peak probably consists of high molecular weight forms of metenkephalin which have been found also in the peripheral blood of dogs with experimentally induced shock (Evans et al., 1984; Medbak et al., 1987). $\beta$-Endorphin and met-enkephalin values therefore have to be interpreted as immunoreactivity.

In cows there seems to be a continuous increase in plasma $\beta$-endorphin concentration during gestation. Levels at parturition, however, were only slightly different from those before the onset of labour. This differs from results obtained for women in which no increase in plasma $\beta$-endorphin concentrations could be detected before parturition (Csontos et al., 1979; Hoffman et al., 1984). However, in rats Petraglia et al. (1985) found a continuous increase in plasma $\beta$-endorphin levels during pregnancy, which is comparable to our results.

Plasma met-enkephalin IR concentrations in cows in the 3rd and 6th months of gestation were lower than those in cows during the last month of pregnancy. A further increase occurred in animals actually in labour. In women in labour Panerai et al. (1983) found no increase in plasma met-enkephalin levels. However, in the cerebrospinal fluid Terenius et al. (1987) detected higher enkephalin values in women shortly before delivery than in non-pregnant controls. The pre-partum increase in plasma $\beta$-endorphin and to a smaller extent also met-enkephalin concentrations is most probably related to other pregnancy-associated endocrine changes. No correlation existed between mode of delivery and $\beta$-endorphin IR concentrations in cows at parturition. Even in animals with a preterm Caesarean section high concentrations of $\beta$-endorphin IR were found. In these cows plasma progesterone concentrations were still high, indicating that pre-partum luteolysis had not yet occurred. The first sample was taken before surgery so that a surgery-related influence on $\beta$-endorphin can be excluded. The stress of labour and delivery does not seem to influence plasma $\beta$-endorphin IR levels in cows. A direct stimulation of peripheral $\beta$-endorphin secretion caused by pain and 'psychological stress' of labour, as described for women (Steinbrook et al., 1982; Hoffman et al., 1984), does not seem to exist in cattle. Plasma met-enkephalin 
IR seems to be related more closely to parturition than is $\beta$-endorphin. Cows with term delivery had higher met-enkephalin plasma concentrations than animals during the last month of gestation.

In conjunction with a term Caesarean section we found a further increase in plasma $\beta$-endorphin and met-enkephalin concentrations during surgery. This is not surprising since certain forms of stress led to the release of opioid peptides into the circulation. This seems to be true also for the stress caused by a Caesarean section under local anaesthesia. Our results agree with those of Räisänen et al. (1986) who found an increase in plasma $\beta$-endorphin values during surgery in women undergoing Caesarean section.

In cows with preterm Caesarean section, no increase in met-enkephalin IR and only a small rise in $\beta$-endorphin IR occurred. This observation suggests that a partial inhibition of stress-induced opioid release may exist before luteolysis or onset of parturition.

The concentrations of both opioids gradually decreased over $12 \mathrm{~h}$ post partum. Considering the short half-life for $\beta$-endorphin (Reid et al., 1981) and met-enkephalin (Hambrook et al., 1976) in blood, a continuing, elevated secretion of both peptides has to be assumed for the immediate post-partum period. $\beta$-Endorphin and met-enkephalin were not significantly correlated in cows or in calves. A common regulatory mechanism for both peptides is unlikely. Between calves born spontaneously and those with complicated delivery requiring veterinary assistance $\beta$-endorphin values were not different. Even a spontaneous delivery seems to stimulate an almost maximal release of $\beta$-endorphin in calves. Before rupture of the umbilical cord $\beta$-endorphin and metenkephalin IR levels in plasma were significantly lower than immediately after birth. This increase does not seem to be related to the mode of delivery but may be triggered by changes connected with the adaptation to the extrauterine environment following umbilical cord rupture. It may be argued that before birth the placenta may contribute to the clearance of opioids from the fetal circulation. This could lead to lower concentrations of $\beta$-endorphin and met-enkephalin IR in the fetus than after birth. However, if a significant placental clearance of opioids existed, an arterio-venous difference in the umbilical vessels should be expected, which could not be substantiated in our study.

In calves delivered before term, met-enkephalin concentrations in samples from the umbilical vessels were lower than in calves from term Caesarean sections. This can be explained by the fact that calves after preterm delivery had not been exposed to the changes accompanying labour. A significant correlation existed immediately and at $1 \mathrm{~h}$ after birth between $\beta$-endorphin and metenkephalin IR concentrations and the degree of acidosis in calves, as found by Wardlaw et al. (1979) for human babies. We cannot conclude that a cause-effect relationship exists between acidosis and the release of peripheral opioid peptides. However, hypoxia and acidosis increase metenkephalin (Farrell et al., 1983) and catecholamine (Cohen et al., 1984; Greenough et al., 1987; Martinez et al., 1988) secretion from the adrenal medulla. An experimental endotoxin shock induced a parallel release of met-enkephalin and catecholamines, although the adrenal is not the only source of circulating met-enkephalin (Watson et al., 1988). In agreement with these observations we found a much closer correlation between acidosis and met-enkephalin IR than with $\beta$-endorphin IR. Since the primate fetal adrenal is already able to synthesize catecholamines and enkephalins at birth (Wilburn et al., 1986), a co-secretion of enkephalins and catecholamines may also exist in calves.

This work was supported by the H. Wilhelm Schaumann Stiftung and the Studienstiftung des deutschen Volkes. We thank Dr P. V. Malven (Department of Animal Sciences, Purdue University, West Lafayette, IN, USA) for the $\beta$-endorphin antiserum and for methodological help; NIDDK and NHPP, University of Maryland School of Medicine (Baltimore, MD, USA) and NIAMMD (Torrance, CA, USA) for gifts of ACTH and $\beta$-lipotropin; and Dr N. Parvizi (FAL, NeustadtMariensee, FRG) for advice. 


\section{References}

Baron, S.A. \& Gintzler, A.R. (1987) Effects of hypophysectomy and dexamethasone treatment on plasma $\beta$-endorphin and pain threshold during pregnancy. Brain Res. 418, 138-145.

Clement-Jones, V., Lowry, P.J., Rees, L.H. \& Besser, G.M. (1980) Development of a specific extracted radioimmunoassay for methionine enkephalin in human plasma and cerebrospinal fluid. J. Endocr. 186, 231-234.

Cohen, W.R., Piasecki, G.J., Cohn, H.E., Young, J.B. \& Jackson, B.T. (1984) Adrenal secretion of catecholamines during hypoxemia in fetal lambs. Endocrinology 114, 383-390.

Csontos, K., Rust, M., Höllt, V., Mahr, W., Kromer, W. \& Teschemacher, H.J. (1979) Elevated plasma $\beta$-endorphin levels in pregnant women and their neonates. Life Sci. 25, 835-844.

Ebling, F.J.P. \& Lincoln, G.A. (1987) ß-Endorphin secretion in rams related to season and photoperiod. Endocrinology 120, 809-818.

Evans, S.F., Medbak, S., Hinds, C.J., Tomlin, S.J., Varley, J.G. \& Rees, L.H. (1984) Plasma levels and biochemical characterization of circulating metenkephalin in canine endotoxin shock. Life Sci. 34, 1481-1486.

Farrell, L.D., Harrison, T.S. \& Demers, L.M. (1983) Immunoreactive met-enkephalin in the canine adrenal; response to acute hypovolemic stress. Proc. Soc. exp. Biol. Med. 173, 515-518.

Goland, R.S., Wardlaw, S.L., Stark, R.I. \& Frantz, A.G. (1981) Human plasma $\beta$-endorphin during pregnancy, labor, and delivery. J. clin. Endocr. Metab. 52, 74-78.

Greenough, A., Lagercrantz, H., Pool, J. \& Dahlin, I. (1987) Plasma catecholamine levels in preterm infants, effect of birth asphyxia and apgar score. Acta paediatr. scand. 76, 54-59.

Hambrook, J.M., Morgan, B.A., Rance, M.J. \& Smith, C.F.C. (1976) Mode of deactivation of the enkephalins by rat and human plasma and rat brain homogenates. Nature, Lond. 262, 782-783.

Hoffman, D.T., Abboud, T.K., Haase, H.R., Hung, T.T. \& Goebelsmann, U. (1984) Plasma beta-endorphin concentrations prior to and during pregnancy, in labor, and after delivery. Am. J. Obstet. Gynecol. 150, $492-496$

Hoffmann, B., Kyrein, H.J. \& Ender, M.L. (1973) An efficient procedure for the determination of progesterone by radioimmunoassay applied to bovine peripheral plasma. Horm. Res. 4, 302-310.

Irestedt, L., Lagercrantz, H., Hjemdahl, P., Haegnevik, K. \& Belfrage, P. (1982) Fetal and maternal plasma catecholamine levels at elective cesarean section under general or epidural anesthesia versus vaginal delivery. Am. J. Obstet. Gynecol. 142, 1004-1010.

Martinez, A., Padbury, J., Shames, L., Evans, C. \& Humme, J. (1988) Naloxone potentiates epinephrine release during hypoxia in fetal sheep: dose response and cardiovascular effects. Pediatr. Res. 23, 343-347.
Medbak, S., Mason, D.F.J. \& Rees, L.H. (1987) Plasma met-enkephalin and catecholamine responses to insulin-induced hypoglycemia in greyhounds. $J$. Endocr. 114, 81-87.

Panerai, A.E., Martini, A., Di Giulio, A.M., Fraioli, F., Vegni, C., Pardi, G., Marini, A. \& Mantegazza, P. (1983) Plasma $\beta$-endorphin, $\beta$-lipotropin, and met-enkephalin concentrations during pregnancy in normal and drug-addicted women and their newborn. J. clin. Endocr. Metab. 57, 537-543.

Petraglia, F., Baraldi, M., Giarre, G., Facchinetti, F., Santi, M., Volpe, A. \& Genazzani, A.R. (1985) Opioid peptides of the pituitary and hypothalamus: changes in pregnant and lactating rats. $J$. Endocr. 105, 239-245.

Räisänen, I., Paatero, H., Salminen, K. \& Laatikainen, T. (1986) $\beta$-Endorphin in maternal and umbilical cord plasma at elective cesarean section and in spontaneous labor. Obstet. Gynecol. 67, 384-387.

Reid, R.L., Hoff, J.D., Yen, S.S.C. \& Li, C.H. (1981) Effects of exogenous $\beta_{h}$-endorphin on pituitary hormone secretion and its disappearance rate in normal human subjects. J. clin. Endocr. Metab. 52, 1179-1184.

Ruth, V., Pohjavuori, M., Rovamo, L., Salminen, K. \& Laatikainen, T. (1986) Plasma $\beta$-endorphin in perinatal asphyxia and respiratory difficulties in newborn infants. Pediatr. Res. 20, 577-580.

Skillman, C.A. \& Clark, K.E. (1987) Fetal betaendorphin levels in response to reductions in uterine blood flow. Biol. Neonate 51, 217-223.

Steinbrook, R.A., Carr, D.B., Datta, S., Naulty, J.S., Lee, C. \& Fisher, J. (1982) Dissociation of plasma and cerebrospinal fluid beta-endorphin-like immunoreactivity levels during pregnancy and parturition. Anesth. Analg. 61, 893-897.

Terenius, L., Lyrenäs, S., Lutsch, H., Lindström, L., Nyberg, F. \& Lindberg, B. (1987) Opioid peptides at term pregnancy, in the early puerperium and in postpartum psychosis. Adv. Biochem. Psychopharmacol. 43, 201-209.

Wardlaw, S.L. \& Frantz, A.G. (1983) Brain $\beta$-endorphin during pregnancy, parturition, and in the postpartum period. Endocrinology 113, 1664-1668.

Wardlaw, S.L., Stark, R.I., Baxi, L. \& Frantz, A.G. (1979) Plasma $\beta$-endorphin and $\beta$-lipotropin in the human fetus at delivery: correlation with arterial $\mathrm{pH}$ and $\mathrm{pO}_{2}$. J. clin. Endocr. Metab. 49, 888-891.

Watson, J.D., Varley, J.G., Bouloux, P.M., Tomlin, S.J., Rees, L.H., Besser, G.M. \& Hinds, C.J. (1988) Adrenal vein and arterial levels of catecholamines and immunoreactive metenkephalin in canine endotoxin shock and their response to naloxone. Res. exp. Med. 188, 319-328.

Wilburn, L.A., Goldsmith, P.C., Chang, K.-J. \& Jaffe, R.B. (1986) Ontogeny of enkephalin and catecholamine-synthesizing enzymes in the primate fetal adrenal medulla. J. clin. Endocr. Metab. 63, 974-980.

Received 3 November 1989 